\title{
Continuous Lactation in Dairy Cows: Effect on Milk Production and Mammary Nutrient Supply and Extraction
}

\author{
T. G. Madsen, ${ }^{*}$ M. O. Nielsen, ${ }^{\star 1}$ J. B. Andersen, $\dagger$ and K. L. Ingvartsen† \\ *Department of Basic Animal \& Veterinary Sciences, Faculty of Life Sciences, University of Copenhagen, Grønnegaardsvej 7 , \\ DK-1870 Frederiksberg C, Denmark \\ †Department of Animal Health, Welfare and Nutrition, Faculty of Agricultural Sciences, University of Aarhus, PO Box 50, \\ DK-8830 Tjele, Denmark
}

\begin{abstract}
Reports over the past decade have indicated that normal lactational performance can be achieved in genetically superior and high-producing dairy cows, even when the dry period between 2 lactations is omitted. The hypothesis tested in this experiment was that normal lactogenesis I and metabolic function may be achievable in continuously milked high-yielding dairy cows as a result of the genetic selection for lactation performance and hence longevity of mammary epithelial cells. The milk production and mammary nutrient uptake in response to omission of the dry period for cows with an expected peak milk yield higher than 45 $\mathrm{kg} / \mathrm{d}$ were studied in 28 Holstein dairy cows managed without bovine somatotropin. Performance and metabolic parameters were followed in late gestation and in the following early lactation. Fourteen cows were milked continuously throughout late gestation, and another 14 dairy cows experienced a 7-wk prepartum dry period. Continuous milking during the prepartum period reduced milk production in the following early lactation period by $>20 \%$. The reduced milk production could not be readily ascribed to inefficiency of the mechanisms responsible for nutrient uptake by the lactating mammary epithelial cells, nor to systemic endocrine changes. This suggests that lowered mammary nutrient uptake must have been associated with reduced mammary blood flow, metabolic activity, or both, most likely as a result of disturbed lactogenesis I prepartum or lactogenesis II postpartum triggered by as yet unknown local mechanisms. Milk protein content was elevated by 0.4 percentage units in the continuously milked cows. The underlying reason is unknown, but given the current pricing system for milk, it deserves to be further investigated.
\end{abstract}

Received November 30, 2007.

Accepted February 4, 2008.

${ }^{1}$ Corresponding author: mon@life.ku.dk
Key words: continuous milking, dry period, mammary metabolism, mammary nutrient uptake

\section{INTRODUCTION}

Successful dairy cow management traditionally includes a dry period between successive lactation periods. However, the genetic potential for milk production has increased dramatically during the last decades, which means that the milk yield at the time of dry-off often exceeds $30 \mathrm{~kg} / \mathrm{d}$, and some dairy scientists and producers have expressed concern that drying off of such high-yielding cows could have a negative effect on health of the cows (Lormore and Galligan, 2001).

Metabolic disorders including fatty liver, ketosis, and hypocalcemia in the peripartuent period can furthermore be related to the large changes in nutrient metabolism occurring at the onset of the new lactation, which is associated with a dramatic increase in mammary nutrient uptake, resulting in more or less extensive mobilization of body reserves, especially fat (Ingvartsen, 2006).

One way to decrease the quantitatively large change in nutrient metabolism around parturition could be to omit the dry period (i.e., let the cow lactate continuously from one lactation into the next). This practice has, however, in older studies been shown to decrease production in the subsequent lactation by 20 to $40 \%$ (Sanders, 1928; Swanson, 1965; Smith et al., 1967). More recent studies have also shown a reduction of approximately $20 \%$ when omitting the dry period (Remond et al., 1997a). It was therefore somewhat surprising when Remond and Bonnefoy (1997) reported that one of the highest yielding dairy herds in France practiced continuous lactation, and the same has been reported for the highest producing dairy herd in Denmark around the year 2000 (Olesen, 2002). A study involving 3 commercial dairy herds in the United States showed that milk production was not affected by a continuous milking strategy in multiparous cows treated with somatotropin (Annen et al., 2004). Levels of milk production in all 
these experimental studies have all been relatively low (20 to $30 \mathrm{~kg} / \mathrm{d}$ at peak lactation in control cows) compared with the production level in some commercial herds. It has been shown that high-producing cows are less sensitive to shortening of the dry period than loweryielding cows (Farries and Hoheisel, 1989), which may suggest that milk production of high-yielding cows could be less negatively affected in the following lactation by continuous lactation.

The capacity for milk production is determined by number of secretory cells and activity of the individual cell. According to Knight and Wilde (1987), the declining milk production after the production has peaked is mainly due to decreasing number of active secretory cells. In late pregnancy, the mammary epithelial cell population is renewed (lactogenesis I). Capuco and Akers (1999) have shown that continuous lactation in dairy cows during late pregnancy may interfere with the cell renewal in lactogenesis I by lowering the formation of new cells, whereas total cell number apparently is not affected compared with cows managed with a prepartum dry period. As a result, a higher number of old alveolar cells are being carried over from the previous lactation to the next in the continuously milked mammary gland. This has also been observed in rats with no dry period in between 2 lactations (Pitkow et al., 1972). The cows in the study by Capuco and Akers (1999) were killed before parturition, and the effect on their milk production in the next lactation therefore not known. It seems obvious to assume that the depressing effect of continuous lactation on milk production in the following lactation is a result of an older and less active population of mammary epithelial cells. It is, however, also tempting to hypothesize that lactogenesis I and mammary metabolic function in genetically superior and high-producing dairy cows may have become less dependent on the dry period as a result of higher lactation persistency and longevity of mammary epithelial cells.

The objectives of the present study were therefore to examine the effect of omitting the dry period in dairy cows, managed without somatotropin (ST), on milk production and mammary metabolism due to onset of a new lactation. This was done by comparing 2 groups of cows, of which one group was allowed a prepartum dry period of approximately $7 \mathrm{wk}$ and the other group was milked continuously into the next lactation.

\section{MATERIALS AND METHODS}

\section{Animals, Experimental Design, and Feeding}

All animal experimental procedures were conducted under the protocols approved by the Danish Animal Experiments Inspectorate and complied with the laws of the Danish Ministry of Justice concerning animal experimentation and care of experimental animals.

The experimental animals, design, and feeding have previously been reported (Andersen et al., 2005). In short, a homogeneous group of 28 Danish Holstein dairy cows, 11 in first lactation, 16 in second lactation, and 1 in third lactation, were selected among the cows with the highest merit for milk yield and a good health record in the dairy herd of the Faculty of Agricultural Sciences, University of Aarhus, Denmark.

Seven weeks before expected calving, the cows were blocked according to genetic merit of milk yield, lactation number, and BW after calving in the first lactation and were then randomly allocated to 1 of 2 experimental groups according to expected calving dates. A total of 11 cows were assigned to group 1, in which the cows were dried off approximately 7 wk prepartum, and 17 cows were assigned to group 2 , in which the cows were milked continuously until parturition unless daily milk yield declined to less than $5 \mathrm{~kg} / \mathrm{d}$. Due to spontaneous cessation of milk production more than $5 \mathrm{wk}$ prepartum, 3 cows from group 2 were moved to group 1, resulting in 2 equally sized groups of 14 cows in each.

Cows in group 1 ended up with an average dry period of $47 \pm 5$ (SEM) d. In 7 of the cows in group 2, milk yield declined to less than $5 \mathrm{~kg} / \mathrm{d}$, and the cows were subsequently dried off between 12 and $4 \mathrm{~d}$ prepartum, given an average dry period length in these cows of 8 $\mathrm{d}(\mathrm{SEM}=1)$. Two cows from group 1 were excluded due to illness not related to the experimental treatment (amputation of teats following coli mastitis just after calving). Cows that maintained milk production until 2 $\mathrm{d}$ before parturition were considered to have completed continuous lactation.

All cows were fed the same total mixed diet twice a day at 0800 and $1400 \mathrm{~h}$ and had at all times free access to water. The diet contained corn silage (33.3\%), grass silage (20.9\%), rolled barley (10.1\%), dried grass pellets (13.0\%), rapeseed cake (17.6\%), suger beet molasses (4.6\%), and feed urea (0.5\%); see Andersen et al. (2005) for further description. During the first 4 wk of the dry period, until $3 \mathrm{wk}$ before expected calving, the cows in group 1 were fed 6 Danish feed units ( 11.5 MJ of ME) restrictedly of the mixed diet and barley straw ad libitum, according to Danish norms for dry cows. For the rest of the dry period and postpartum, the cows were fed the mixed diet ad libitum. The cows in group 2 were fed the same mixed diet ad libitum throughout the entire experiment. Daily milking was performed at 0430 and 1530 h. All cows were housed in a tie stall system where chopped barley straw was used as bedding. 


\section{Samplings and Measurements}

Body condition score, BW, and daily milk yield were recorded once weekly throughout the whole experimental period. Feed refusals were collected every morning before feeding during all weekdays but not during weekends. Milk samples from morning and evening milkings were collected once every week and stored at $5^{\circ} \mathrm{C}$ until analyzed.

Week 3 before expected calving and wk 1 and 5 postpartum, blood samples were taken 4 times between morning and evening milking at $0700,1000,1300$, and $1600 \mathrm{~h}$ by vein puncture from 1 jugular and 1 milk vein and collected in 2 tubes containing either EDTA or heparin (Becton Dickinson Vacutainer Systems, Plymouth, UK). Blood samples were kept on ice until plasma was separated by centrifugation $(20 \mathrm{~min}, 2,000 \times g$, $4^{\circ} \mathrm{C}$ ). Aliquots of the plasma were stored at $-20^{\circ} \mathrm{C}$ until analyses were performed.

\section{Analyses}

Glucose, BHBA, NEFA, and triacylglycerol (TAG) analyses were performed on heparin plasma sample aliquots, and acetate was performed on EDTA plasma sample aliquots. Commercial spectrophotometrical kits were used to analyze for acetate (Boehringer Mannheim, Germany), NEFA (Wako Chemicals GmbH, Neuss, Germany), glucose, BHB, and TAG (Sigma-Aldrich, Copenhagen, Denmark).

Plasma insulin, IGF-I, total thyroxine $\left(\mathbf{T}_{4}\right)$, and ST were analyzed as described by Mashek et al. (2001). Feed samples were analyzed as described by Ingvartsen et al. (2001). Milk protein, fat, lactose, and cell contents were determined by a MilkoScan FT 120 (Foss Electric A/S, Hillerød, Denmark).

\section{Calculations}

Energy-corrected milk containing $3.14 \mathrm{MJ} / \mathrm{kg}$ was calculated from the determined yields of protein, fat, and lactose $[\mathrm{ECM}(\mathrm{kg} / \mathrm{d})=23.8 \times($ protein yield in $\mathrm{kg} /$ d) $+38.9 \times($ fat yield in $\mathrm{kg} / \mathrm{d})+16.3 \times$ (lactose yield in $\mathrm{kg} / \mathrm{d}) / 3.14$ ]. Mammary extraction rates of metabolites were estimated as mammary jugular-milk vein concentration difference (JM-difference) as a percentage of jugular concentration (extraction $=$ JM-difference/jugular concentration $\times 100$ ). Plasma total long-chain fatty acids (Kincaid et al., 1991) concentration was calculated as NEFA concentration $+3 \times$ TAG concentration.

\section{Statistics}

Treatment effects and temporal differences in milk yield, milk protein, fat, and lactose content and milk protein, fat, and lactose yield were estimated using the restricted maximum likelihood method in the mixed model procedure in SAS version V8 (SAS Institute Inc., Cary, NC). Significant autocorrelation between repeated measurements in different weeks within animals was taken into account by defining covariance structure as described in model I:

$$
\begin{aligned}
\mathrm{Y}_{\mathrm{ijkl}}= & \mu+\text { block }_{\mathrm{i}}+\text { treatment }_{\mathrm{j}}+\text { cow }_{\mathrm{k}}\left(\text { treatment }_{\mathrm{j}}\right. \\
& + \text { week }_{1}+\left(\text { treatment week }_{\mathrm{j} 1}+\varepsilon_{\mathrm{ijkl}}\right.
\end{aligned}
$$

where $\mathrm{Y}=$ the dependent variable; $\mu=$ the overall mean; block $=$ fixed effect of block $(i=1,2, . ., 5)$; treatment $=$ fixed effect of treatment $(j= \pm$ dry period); cow (treatment $)=$ random effect of cow $\mathrm{k}$ within treatment $\mathrm{j}$, $\left\{\operatorname{cow}_{k}(\text { treatment })_{j}\right\} \sim N$; week $=$ fixed effect of week l postpartum $(l=1,2, \ldots, 7)$; (treatment week $)_{j l}=$ interaction between dry period treatment $\mathrm{j}$ and week $\mathrm{l}$ of lactation; and $\varepsilon=$ random variation, $\left\{\varepsilon_{\mathrm{ijk}}\right\} \sim \mathrm{N}\left(0, \sigma^{2}\right)$. Results were expressed as least squares means with standard error of mean. Because the variance was homogeneous over week $l$ and there was a significant correlation between $l$ and $l^{\prime}$, a simple covariance structure was chosen.

Treatment effects and differences between lactation stages in plasma nutrient and hormone concentration, mammary nutrient uptake, and milk composition were also estimated using the restricted maximum likelihood method in the mixed model procedure in SAS. Pre- and postpartum data were analyzed separately. All statistical analyses on plasma hormones were performed on natural log-transformed data. Significant autocorrelation between repeated measurements at different times during the day within animals was taken into account by defining covariance structure as described in model II:

$$
\begin{aligned}
& \mathrm{Y}_{\mathrm{ijklm}}=\mu+\text { block }_{\mathrm{i}}+\text { treatment }_{\mathrm{j}}+\text { stage }_{\mathrm{k}} \\
& +(\text { treatment stage })_{\mathrm{ik}}+\text { cow }_{\mathrm{l}}(\text { treatment stage })_{\mathrm{jk}} \\
& + \text { time }_{\mathrm{m}}+(\text { treatment time })_{\mathrm{jm}}+(\text { stage time })_{\mathrm{km}} \\
& +(\text { treatment stage time })_{\mathrm{jkm}}+\varepsilon_{\mathrm{ijklm}}
\end{aligned}
$$

where $\mathrm{Y}=$ the dependent variable; $\mu=$ the overall mean; block $=$ fixed effect of block $(i=1,2, . ., 5)$; treatment $=$ fixed effect of treatment $(\mathrm{j}= \pm$ dry period); stage $(\mathrm{k}=$ 1 or $5 \mathrm{wk}$ postpartum); treatment stage $=$ interaction between dry period treatment $\mathrm{j}$ and stage $\mathrm{k}$ of lactation; cow $($ treatment stage $)=$ random effect of cow l within treatment $\mathrm{j}$ and stage $\mathrm{k}$ of lactation, $\left\{\mathrm{cow}_{\mathrm{l}}\right.$ (treatment stage $\left.)_{\mathrm{jk}}\right\} \sim \mathrm{N}$; time $=$ fixed effect of time of the day $(\mathrm{m}=$ $7,10,13,16 \mathrm{~h}$ ); (treatment time) ${ }_{\mathrm{jm}}$, (stage time) $)_{\mathrm{km}}$, (treatment stage time $)_{\mathrm{jkm}}=$ interactions; and $\varepsilon=$ random variation, $\left\{\varepsilon_{\mathrm{ijk} k \mathrm{~m}}\right\} \sim \mathrm{N}\left(0, \sigma^{2}\right)$. Because the variance 
was homogeneous over time $\mathrm{m}$ and there was a significant correlation between $l$ and $l^{\prime}$, a simple covariance structure was chosen in this model. Results were expressed as least squares means with standard error of mean. The pdiff command in SAS was used to generate comparisons between least squares means of different stages within treatments in model II.

\section{RESULTS}

\section{Milk Yield and Composition}

In the continuously milked group, milk yields dropped below $5 \mathrm{~kg} / \mathrm{d}$, and milkings were stopped in 7 of the 14 cows between the last 12 and $4 \mathrm{~d}$ prepartum. Milk production in the following lactation in these 7 cows compared with the cows that were milked continuously (below $2 \mathrm{~d}$ dry) are shown in Figure 1. Although small numerical differences were found, no significant effects postpartum on ECM and milk contents of protein, fat, and lactose were found $(P=0.67,0.27,0.99$, and 0.40 , respectively) between the cows that completed a continuous lactation compared with the cows that dried themselves off spontaneously. All 14 continuously milked cows were therefore treated as 1 group in the statistical analysis.

Table 1 presents afternoon yields of milk and ECM and protein, fat, and lactose content in cows managed with or without a dry period prepartum. The afternoon milk represents milk produced during the period of day over which the jugular-milk venous blood samplings were performed in wk 1 and 5 postpartum. Milk volume, ECM, and lactose content increased in the continuously milked cows, but not in the dried-off cows, from wk 1 to 5 postpartum. Milk protein and fat content decreased in both groups of cows during the same period. Protein content was consistently approximately 0.4 percentage units higher in the continuously milked group compared with the dried-off cows. No effect of prepartum treatment was observed for milk fat and lactose contents. The high protein content in milk from continuously milked cows could not compensate for lower milk yield, and yields of protein were significantly lower in continuously milked cows compared with cows with a previous dry period. This was even more pronounced for lactose and fat yields. The difference in ECM between the 2 treatment groups diminished from wk 1 to 5 of lactation, resulting in a significant interaction between week of lactation and prepartum treatment $(P$ $<0.01$ ). As previously reported (Andersen et al., 2005), daily ECM was, however, depressed by more than $20 \%$ on average over the first 6 wh of lactation in the cows without a dry period, although postpartum feed intake did not differ between the 2 treatment groups.

\section{Jugular Concentrations, Jugular-Milk Vein Concentration Differences, and Mammary Extraction of Plasma Metabolites}

Prepartum, the dry cows, as shown in Table 2, had a lower jugular glucose concentration and a higher TAG and tended to have lower acetate $(P=0.06)$ compared with the continuously milked cows, but no differences were found for BHBA and NEFA concentrations. Except for NEFA, all JM-differences were positive and significantly different from zero in the continuously milked cows, whereas none of the JM-differences were significantly different from zero in the dry cows prepartum (Table 2).

Postpartum, as shown in Table 2, the jugular concentration of glucose was lowest in the cows with a normal dry period prepartum. No treatment effect was observed for the JM-difference, and hence, mammary glucose extraction (JM-difference/jugular vein concentration) was more efficient in the cows with a previous dry period. For acetate, no prepartum treatment effects were found for neither jugular concentration nor JMdifference. However, acetate extraction in early lactation tended to be highest $(P=0.054)$ in the cows with a previous dry period due to numerically higher JMdifference. Although numerically higher jugular concentrations of BHBA were found in cows with a previous dry period compared with the continuously milked cows, the treatment effect did not reach significance $(P=0.13)$. The JM-difference and mammary extraction for BHBA in early lactation were not affected by prepartum treatment.

Cows with a previous dry period had significantly higher jugular NEFA concentrations in agreement with the lower glucose concentrations, and this was associated with several-fold higher JM-difference for NEFA and mammary extraction rates in these cows. For TAG, no treatment effects were observed for neither jugular concentrations nor mammary JM-difference and extraction.

From wk 1 to 5, jugular concentration of glucose and acetate increased significantly, although the increase in glucose was mainly seen in the prepartum dried cows resulting in an interaction between treatment and week of lactation. Associated with the increase in glucose, jugular NEFA concentrations decreased, whereas jugular BHBA and TAG did not change during the early lactation period.

The JM-difference and mammary extraction increased from wk 1 to 5 for acetate, BHBA, and TAG, corresponding with the increase in milk yield during this period. For NEFA, however, JM-difference decreased dramatically and mammary extraction also de- 


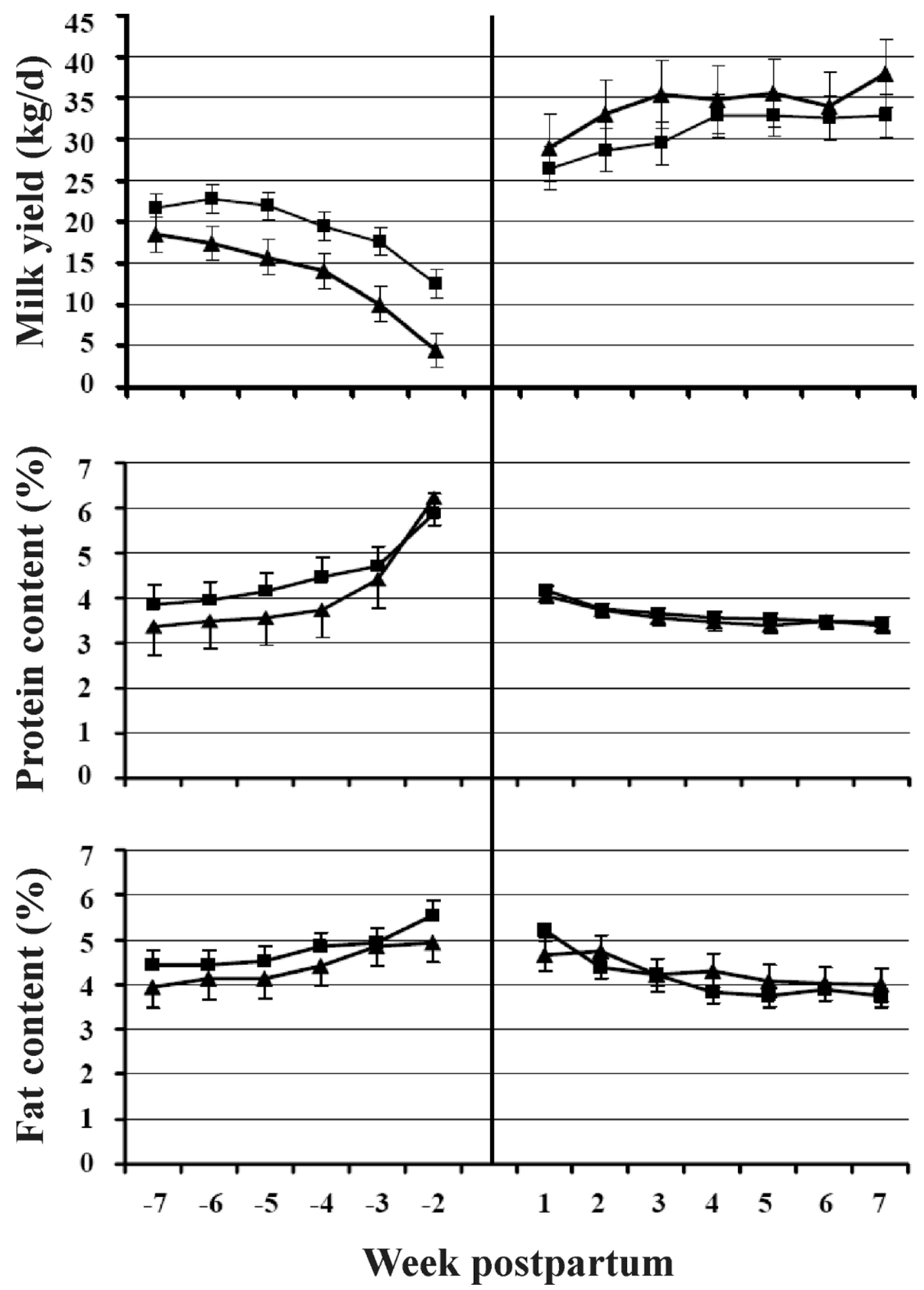

Figure 1. Energy-corrected milk yield, milk protein, and milk fat content in prepartum milked dairy cows, which dried off spontaneously 12 to $4 \mathrm{~d}$ prepartum $(\bullet)$ or completed continuous milking throughout the prepartum period $(\bigcirc)$.

creased from wk 1 to 5, when jugular NEFA concentration also decreased. Glucose JM-difference and extraction did not change during the early lactation period.
No direct statistical comparisons were made between values obtained pre- and postpartum for jugular concentrations and mammary uptake characteristics of the 
Table 1. Afternoon milk yield, ECM yield, content, and yield of protein, fat, and lactose at 2 lactation stages ( 1 and 5 wk postpartum) in dairy cows managed with (Dry) or without (Cont) a dry period prepartum ${ }^{1}$

\begin{tabular}{|c|c|c|c|c|c|c|c|c|c|}
\hline \multirow{2}{*}{$\begin{array}{l}\text { Least squares } \\
\text { means }\end{array}$} & \multicolumn{3}{|c|}{ Dry } & \multicolumn{3}{|c|}{ Cont } & \multicolumn{3}{|c|}{$P$-value ${ }^{2}$} \\
\hline & 1 & 5 & $\overline{\mathrm{SED}^{3}}$ & 1 & 5 & $\overline{\mathrm{SED}^{3}}$ & Treat & Stage & Treat $\times$ Stage \\
\hline Milk (kg/d) & 17.1 & 18.9 & 1.5 & $10.5^{\mathrm{a}}$ & $15.6^{\mathrm{b}}$ & 1.3 & $<0.01$ & $<0.01$ & 0.12 \\
\hline $\operatorname{ECM}(\mathrm{kg} / \mathrm{d})$ & 19.4 & 18.0 & 1.6 & $12.2^{\mathrm{a}}$ & $15.7^{\mathrm{b}}$ & 1.5 & $<0.01$ & 0.34 & $<0.03$ \\
\hline Protein (\%) & $3.79^{\mathrm{a}}$ & $3.02^{\mathrm{b}}$ & 0.11 & $4.21^{\mathrm{a}}$ & $3.42^{\mathrm{b}}$ & 0.09 & $<0.01$ & $<0.01$ & 0.88 \\
\hline Fat $(\%)$ & $4.88^{\mathrm{a}}$ & $3.88^{\mathrm{b}}$ & 0.31 & $4.98^{\mathrm{a}}$ & $4.01^{b}$ & 0.28 & 0.65 & $<0.01$ & 0.99 \\
\hline Lactose (\%) & 4.67 & 4.82 & 0.08 & $4.68^{\mathrm{a}}$ & $4.90^{\mathrm{b}}$ & 0.07 & 0.43 & $<0.01$ & 0.53 \\
\hline
\end{tabular}

${ }^{\mathrm{a}, \mathrm{b}}$ Values with different superscript letters within treatment and row are significantly different $(P<0.05)$.

${ }^{1}$ Afternoon milking represent the period from 0430 to $1530 \mathrm{~h}$ (i.e., $11 \mathrm{~h}$ in total).

${ }^{2}$ Test for treatment effect of a 7 -wk prepartum dry period vs. continuous milking (Treat) in wk 1 vs. 5 postpartum (Stage) and the interaction (Treat $\times$ Stage).

${ }^{3}$ Standard error of difference within treatment.

measured metabolites. However, by comparing the data presented in Table 2, glucose concentrations appeared to decrease and BHBA increase from wk 3 prepartum to wk 1 postpartum in the cows that were dried off prepartum, whereas no changes were seen in the continuously milked cows. The NEFA and TAG jugular concentrations, respectively, were markedly increased and decreased from late gestation to early lactation in both groups of cows. The JM-difference 1 wk postpartum were in general at a higher level for both groups of cows compared with prepartum levels (with the exception of TAG in the continuously milked cows). The postpartum increases in JM-differences were, however, modest for acetate and BHBA in the continuously milked cows.

The JM-difference depended on jugular plasma concentration $(P<0.05)$ in a linear (glucose and acetate) or curvilinear fashion [BHBA and long-chain fatty acids (LCFA)] within the different stages of lactation (results not shown). Prepartum treatment did not affect the slopes or intercepts of the glucose, acetate, and BHBA curves significantly. For LCFA, the regression curve was found to be steeper for the prepartum dried cows compared with the continuously milked cows.

\section{Concentration of Hormones}

As shown in Figure 2, the highest plasma $\mathrm{T}_{4}$ concentrations were observed in the cows milked continuously during the prepartum period, but $\mathrm{T}_{4}$ concentrations decreased in the same manner in both groups of cows during the prepartum period. None of the other hormones (insulin, IGF-I, and ST) were affected by whether cows were dried off or milked continuously during the last $7 \mathrm{wk}$ before parturition. However, IGF-I and ST concentrations were numerically higher and decreased more in the dried-off cows during the prepartum period compared with the continuously milked cows, resulting in significant treatment-week interactions.
At parturition, insulin concentrations dropped to lower levels $(P<0.001)$ in the cows with a previous dry period compared with the cows milked continuously during late gestation but also increased faster in the dried-off cows during the early postpartum period. This tendency was also observed for IGF-I $(P=0.098)$. Concentrations of ST were higher right after parturition compared with the prepartum period in the cows with a previous dry period but gradually normalized in these cows over the first few weeks postpartum, resulting in a close to significant treatment $\times$ week interaction $(P=$ 0.074 ). The $\mathrm{T}_{4}$ concentrations changed in a similar way in the 2 groups of cows postpartum, with a small decrease right after parturition followed by a gradual increase over the first few weeks.

\section{DISCUSSION}

A companion paper (Andersen et al., 2005) describes in detail the findings in the present experiment on feed intake, milk production, and energy metabolism in the peripartum period, when the dry period was omitted in high-yielding dairy cows. The focus in this paper will therefore be on how continuous lactation during the prepartum period affects the mammary capacity for milk synthesis and uptake of nutrients in the new lactation. This will be discussed in relation to the prepartum redevelopment of the mammary epithelium.

\section{Milk Yield and Mammary Synthetic Capacity}

The results of the present experiment support findings in other experimental studies, in which omission of the dry period had a marked negative effect on milk production in the subsequent lactation (Sanders, 1928; Swanson, 1965; Smith et al., 1967). The milk yield depression over the first $6 \mathrm{wk}$ of lactation in the continuously milked cows in our studies was $>20 \%$ (Andersen et al., 2005), although milk production in the control 
Table 2. Jugular plasma concentration (JV), jugular-milk vein concentration difference (JM), and mammary extraction (Ext) of glucose, acetate, BHBA, NEFA, triacylglycerol (TAG), and total long-chain fatty acids (LCFA) at 3 wk prepartum and 1 and 5 wk postpartum in dairy cows managed with a 7-wk dry period (dry) or milked continuously (Cont) prepartum

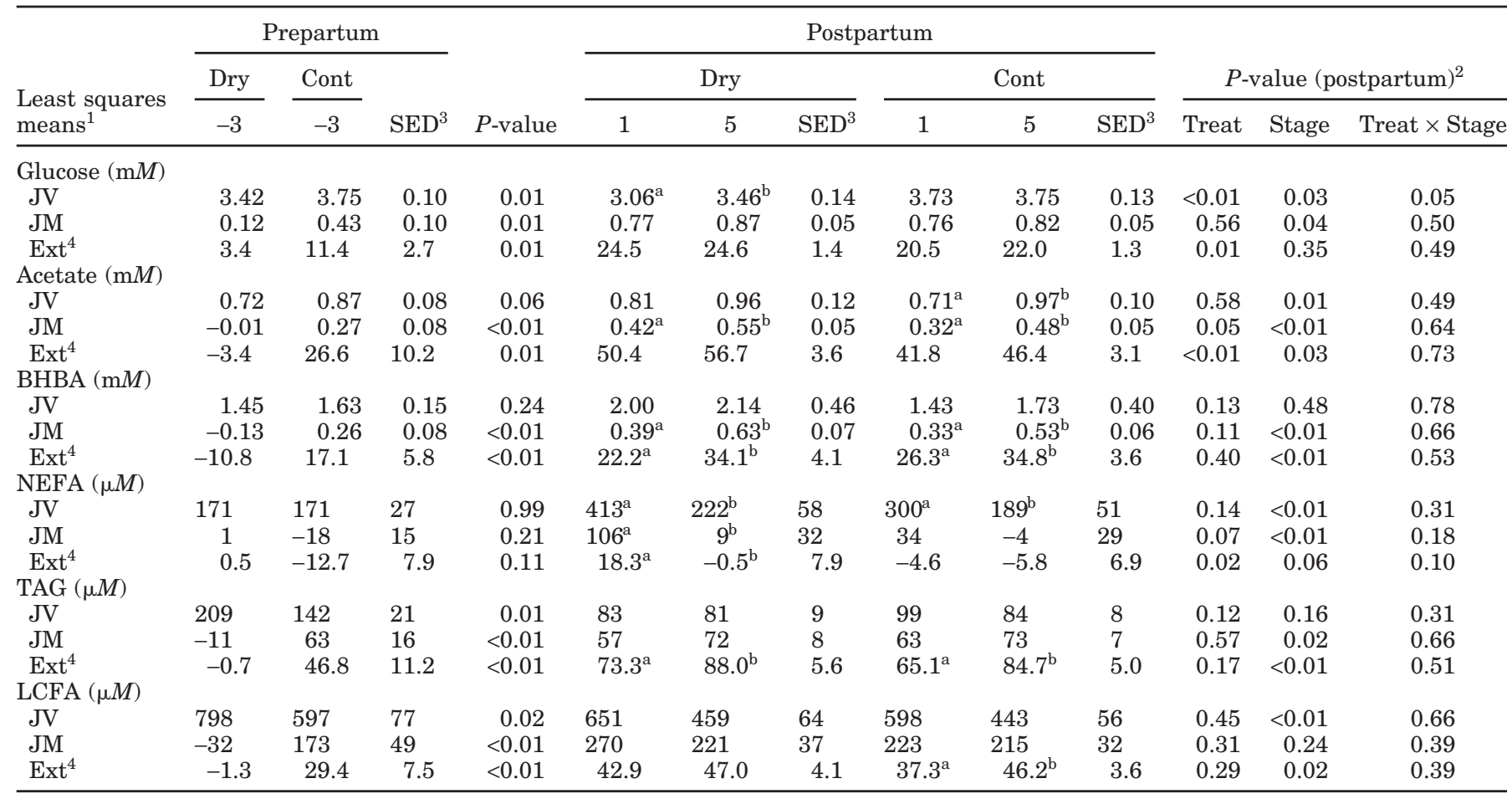

${ }^{\mathrm{a}, \mathrm{b}}$ Values with different superscript letters within treatment and row postpartum are significantly different $(P<0.05)$.

${ }^{1}$ Least squares mean values of 4 samples obtained between morning and evening milking.

${ }^{2}$ Test for treatment effect of a 7 -wk prepartum dry period vs. continuous milking (Treat) in wk 1 vs. 5 wk postpartum (Stage) and the interaction (Treat $\times$ Stage).

${ }^{3}$ Standard error of difference.

${ }^{4} \mathrm{Ext}=$ extraction across the mammary gland presented as $\mathrm{JM}$ in $\%$ of $\mathrm{JV}$.

group peaked at a much higher level ( $>45 \mathrm{~kg}$ of ECM/ d) compared with the cows in the older studies but comparable to yields of the previously dried-off udder halves in the cows in the study by Annen et al. (2007). In contrast, in a trial on 3 commercial dairy farms, Annen et al. (2004) found no negative effect on milk yield when omitting the dry period in lactating STtreated multiparous cows. Cows milked continuously from their first to second lactation did however have a lower milk production postpartum also in this study.

Somatotropin regulates hepatic secretion of IGF-I, and the ST-IGF-I axis is an important endocrine system in the bovine, controlling processes involved in mammary redevelopment in the dry period, including cell death (apoptosis) and proliferation (Accorsi et al., 2002). The findings of Annen et al. (2004) point to the possibility that the ST and IGF-I system can counteract the disruption of mammary cell turnover in cows milked continuously during the prepartum period, whereby bST treatment would ensure a close-to-normal replacement of the senescent mammary epithelial cells in such cows. However, an experimental study was subsequently conducted by Annen et al. (2007) with 8 highyielding dairy cows concluding their first lactation, in which 1 udder half was milked continuously during the prepartum period, whereas the other udder half was dried off $60 \mathrm{~d}$ before parturition. Half of the cows were assigned to bST treatment during late gestation and early lactation, and the other half received no treatment. In this experiment, milk yield was depressed by approximately $50 \%$ in the continuously milked udder halves, and bST treatment had no effect on the magnitude of this milk yield depression. It therefore remains to be understood why high-yielding dairy cows in some commercial herds can be managed without a prepartum dry period (with or without the use of bST) and yet achieve a normal level of milk production postpartum.

Rate of cell proliferation in mammary tissue was found to be higher in dried-off compared with lactating cows during the last 2 mo of pregnancy (Capuco et al., 1997) and in lactating compared with dried-off udder halves within the same cow $8 \mathrm{~d}$ prepartum (Annen et 


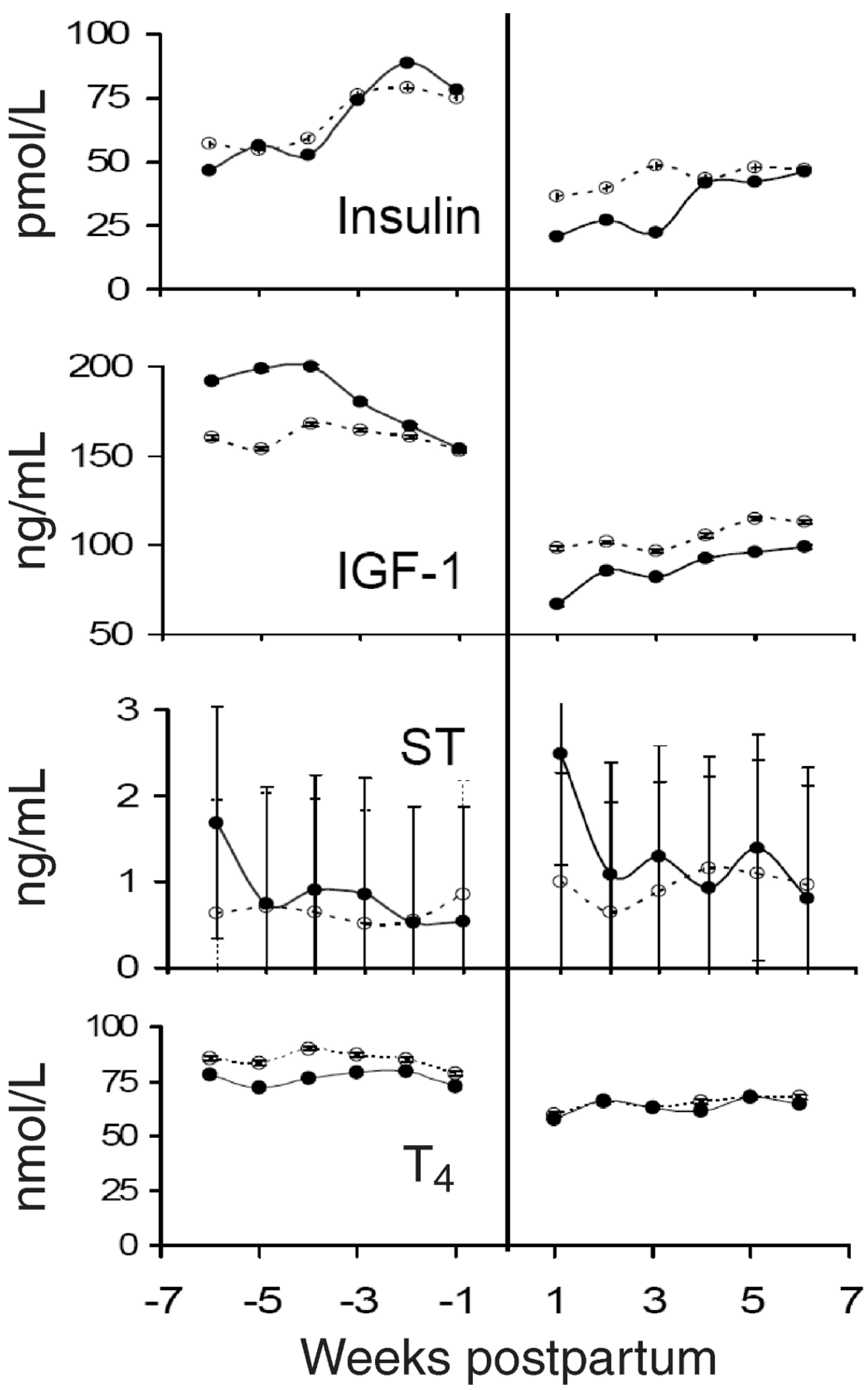

Figure 2. Pre- and postpartum changes in plasma concentrations of insulin, IGF-I, somatotropin (ST), and total thyroxine ( $\left.\mathrm{T}_{4}\right)$ in dairy cows managed with $(-)$ or without $(\bigcirc)$ a 7 -wk prepartum dry period. Data are presented as geometric means of log-transformed data with standard error of the means based on log-transformed data. 
al., 2007). But the amount of parenchyma and the percentage of tissue area occupied by alveolar epithelia were not affected by prepartum milking (Capuco et al., 1997) nor was the content of DNA in continuously milked udder halves compared with dried-off udder halves (Pardue and Swanson, 1963). Continuous milking during the prepartum period thus interferes with the overall mammary cell turnover, associated with renewal of the mammary epithelial cells (Capuco et al., 1997). The slower replacement of the mammary epithelial cells must, on average, result in an increased life span of the mammary epithelial cells in the continuously milked mammary gland, which explains the decreased capacity for milk synthesis, because synthetic activity decreases with ageing of the lactating epithelial cell (Shipman et al., 1987; Knight, 1989). It has, however, not been possible to relate such alterations in cell cycle events to altered expression of specific genes involved in regulation of cell turnover or IGF-I signaling (Annen et al., 2007).

It has been shown that apoptosis is at its highest level about 1 wk after drying off (Quarrie et al., 1996; Wilde et al., 1997). We found no evidence to support an expectation that a very short dry period should have a more pronounced negative effect on milk production in the subsequent lactation compared with continuous lactation as a result of a reduced responsiveness to lactogenic signals around parturition in a mammary epithelial cell population undergoing apoptosis. The cows that dried themselves off very close to term (4 to $12 \mathrm{~d}$ prepartum) in fact had a slightly higher milk production (although not significantly) compared with the truly continuously milking cows, although it was still significantly lower than the dried-off cows.

Milk protein yield was less affected by the prepartum treatment than milk volume, because milk protein content was found to be higher in the continuously milked cows. These observations agree with Farries and Hoheisel (1989) and Remond et al. (1997b), who also found higher milk protein contents in continuously milked cows. The very high protein content in late lactation is probably due to transfer of immunoglobulin to the milk as the cow starts to produce colostrum, and the milk was visually different at this point. However, the consistently higher content of approximately 0.4 percentage units in the subsequent lactation cannot be explained this way. A higher energy balance of continuously milked cows has been suggested as an explanatory factor (Remond et al., 1992). But, an energy status effect can hardly explain the consistent difference we observed throughout the first 6 wk postpartum, in which energy balance had become positive also in the prepartum dried-off cows. Considering the current pricing system that encourages milk with higher protein content, it is of interest to examine which regulatory mechanisms could be responsible for this difference in protein content.

\section{Mammary Nutrient Supply and Uptake}

Jugular vein concentrations of metabolites and JMdifference for these metabolites across the mammary gland are regarded as useful indicators in the study of changes in mammary supply and mammary uptake, respectively, and can provide information about how sensitive uptake of substrates for milk synthesis are to changes in supply of these metabolites to the mammary gland. The jugular concentration is used as an estimate for arterial concentration, because the concentration differences between arterial and jugular plasma in ruminants are negligible for the metabolites studied here (Lykos et al., 1997; Madsen et al., 2005).

The prepartum mammary metabolism was of course totally different in the 2 groups of cows and reflects the fact that the cows in the continuously milked group produced milk prepartum, whereas the other cows did not. The higher prepartum jugular concentrations of glucose and acetate in the continuously milked group were related to the higher feed intake, because these cows were fed ad libitum throughout the experimental period, whereas the dry cows were fed restrictedly until $3 \mathrm{wk}$ prepartum. However, systemic TAG concentration and thereby also total plasma LCFA were lowest in the continuously milked cows prepartum, and this must be an effect of a higher clearance of LCFA by the actively lactating mammary gland in these cows. The higher prepartum JM-difference in the continuously milked group obviously relates to nutrient uptake and utilization in the mammary gland for milk synthesis, which did not occur in the dry cows.

Postpartum, the lower milk production in the continuously milked cows would suggest a lower mammary nutrient uptake in these cows. But the prepartum milking only resulted in lowered JM-difference for acetate and NEFA, and mainly in the first week of lactation, and this was most likely the result of lower systemic plasma concentrations for these 2 nutrients in the continuously milked compared with the prepartum driedoff cows during the first week(s) of lactation. The lack of treatment effect on the JM-differences for the other metabolites could either be explained by a more efficient conversion of the extracted nutrient into milk constituents or more likely by a higher mammary blood flow in the cows with a prepartum dry period. Mammary blood flow has been shown to correlate strongly to milk yield and hence mammary metabolic activity (Davis and Collier, 1985; Nielsen et al., 1990). A higher blood flow through the more metabolically active mammary 
gland of the prepartum dried-off cows could therefore drive the increased mammary nutrient uptake corresponding to the higher output of milk constituents.

As discussed above, continuous lactation prepartum may result in an older population of lactating cells in the following lactation and perhaps a change in the time frame for the remodeling of the mammary gland. It is therefore obvious to believe that the ability of the mammary gland to extract metabolites from the blood would be less efficient in the cow milked continuously prepartum, and the sensitivity of mammary uptake of metabolites to changes in arterial supply could also be altered. We did observe higher mammary extractions of glucose, acetate, and NEFA in the cows, which had been allowed a dry period prepartum. However, the higher extraction of glucose could entirely be ascribed to lower systemic glucose concentration and not a higher JM-difference. Increased NEFA JM-difference and extraction were associated with much higher systemic levels of NEFA, and this did not affect the overall JM-difference or extraction of LCFA. Only in the case of acetate were there more solid indications of a superior efficiency of mammary uptake and extraction in the cows, which had been allowed a dry period prepartum. We have, on the other hand, previously observed increases in acetate extraction, when increased milk yield was induced simply in response to a duodenal protein infusion (T. G. Madsen, unpublished data).

The sensitivity of mammary nutrient uptake toward changes in nutrient supply (JM-difference correlated to jugular concentrations) was not affected by the prepartum milking. The present experiment therefore provides little evidence that the mechanisms responsible for nutrient uptake by mammary epithelial cells are less effective in dairy cows milked continuously during the prepartum period.

\section{Pre- and Postpartum Endocrine Status}

Cows milked continuously throughout the prepartum period do not experience a period of low feed intake, cessation of milk production, and improvement in metabolic status during stepping up of feed intake before parturition. Continuously milked cows could therefore be hypothesized to experience less dramatic metabolic changes associated with initiation of milk production in the new lactation. Higher plasma concentrations in general of insulin and IGF-I and less pronounced decreases in levels of these hormones postpartum in the continuously milked cows did suggest greater ease and a less metabolically challenging transition to lactation. However, this could be ascribed to the much lower level of milk production in these cows postpartum and hardly to improved efficiency of homeorhetic adaptations, and as we have previously reported (Andersen et al., 2005), there were no indications of a higher feed intake capacity postpartum in the continuously milked cows.

Prepartum, we observed the lowest IGF-I concentrations in the continuously milked cows, but this was ascribed to differences observed between the 2 groups of cows only in weeks 6 to 4 before parturition, and IGF-I levels were of similar magnitude in the 2 groups of cows during the last 3 wk of gestation as well as postpartum. As discussed above, the importance of the IGF system in regulation of mammary development is well recognized (Baumrucker and Erondu, 2000). Presumptive differences in mammary epithelial cell renewal before parturition and hence milk production capacity in the mammary gland can, in the present experiment, not be ascribed to a systemic endocrine response in the ST-IGF-I axis associated with drying off or continuous milking. Rather, local as yet unknown mechanisms must be responsible for the depressing effect of continuous milking in the prepartum period on mammary epithelial cell turnover and renewal.

\section{CONCLUSIONS}

In high-yielding dairy cows managed without exogenous bST, continuous milking during the prepartum period reduced milk production in the following early lactation by $>20 \%$. The reduced milk production could not be ascribed to inefficiency of the mechanisms responsible for nutrient uptake by the lactating mammary epithelial cells. This suggests that lowered mammary nutrient uptake may be associated with reduced mammary blood flow and metabolic activity, most likely as a result of disturbance of the prepartum redevelopment or postpartum remodeling of the mammary epithelial cell population triggered by as yet unknown local mechanisms. Milk protein content was elevated by 0.4 percentage units in the continuously milked cows. The underlying reason is unknown, but given the current prizing system for milk, it deserves to be further investigated.

\section{ACKNOWLEDGMENTS}

The Danish Agricultural and Veterinary Research Council and the Danish Cattle Association provided financial support for this study. We want to thank the following laboratory technicians and students at the Faculty of Agricultural Sciences, University of Aarhus (Tjele, Denmark) for their skillful help during sampling and analysis of samples: D. Agnholt, L. Niklassen, J. B. Clausen, J. Adamsen, S. H. Jensen, C. S. Erichsen, and T. B. Pedersen. 


\section{REFERENCES}

Accorsi, P. A., B. Pacioni, C. Pezzi, M. Forni, D. J. Flint, and E. Seren. 2002. Role of prolactin, growth hormone and insulin-like growth factor 1 in mammary gland involution in the dairy cow. J. Dairy Sci. 85:507-513.

Andersen, J. B., T. G. Madsen, T. Larsen, K. L. Ingvartsen, and M. O. Nielsen. 2005. The effects of dry period versus continuous lactation on metabolic status and performance in periparturient cows. J. Dairy Sci. 88:3530-3541.

Annen, E. L., R. J. Collier, M. A. McGuire, J. L. Vicini, J. M. Ballam, and M. J. Lormore. 2004. Effect of modified dry period lengths and bovine somatotropin on yield and composition of milk from dairy cows. J. Dairy Sci. 87:3746-3761.

Annen, E. L., A. C. Fitzgerald, P. C. Gentry, M. A. McGuire, A. V. Capuco, L. H. Baumgard, and R. J. Collier. 2007. Effect of continuous milking and bovine somatotropin supplementation on mammary epithelial cell turnover. J. Dairy Sci. 90:165-183.

Baumrucker, C. R., and N. E. Erondu. 2000. Insulin-like growth factor (IGF) system in the bovine mammary gland and milk. J. Mammary Gland Biol. Neoplasia 5:53-64.

Capuco, A. V., and R. M. Akers. 1999. Mammary involution in dairy animals. J. Mammary Gland Biol. Neoplasia 4:137-144.

Capuco, A. V., R. M. Akers, and J. J. Smith. 1997. Mammary growth in Holstein cows during the dry period: Quantification of nucleic acids and histology. J. Dairy Sci. 80:477-487.

Davis, S. R., and R. J. Collier. 1985. Mammary blood flow and regulation of substrate supply for milk synthesis. J. Dairy Sci. 68:1041-1058

Farries, E., and S. Hoheisel. 1989. The influence of reduced dry periods on some performance and metabolism traits in dairy cows. J. Dairy Sci. 72(Suppl.1):565. (Abstr.)

Ingvartsen, K. L. 2006. Feeding and management related diseases in the transition cow. Physiological adaptations around calving and strategies to reduce feeding-related diseases. Anim. Feed Sci. Technol. 126:175-213.

Ingvartsen, K. L., O. Aaes, and J. B. Andersen. 2001. Effects of pattern of concentrate allocation in the dry period and early lactation feed intake and lactational performance in dairy cows. Livest. Prod. Sci. 71:207-221.

Kincaid, R. L., J. P. McNamara, J. H. Harrison, and S. S. Waltner. 1991. Effects of whole cottonseeds (WCS) and calcium salts of long chain fatty acids (Ca-LCFA) on performance of lactating dairy cows. J. Dairy Sci. 74(Suppl. 1):252. (Abstr.)

Knight, C. H. 1989. Constraints on frequent or continuous lactation. Proc. Nutr. Soc. 48:45-51.

Knight, C. H., and C. J. Wilde. 1987. Mammary growth during lactation: Implications for increasing milk yield. J. Dairy Sci. 70:1991-2000

Lormore, M. J., and D. T. Galligan. 2001. Economics of atypical lactation. J. Dairy Sci. 84(E Suppl.):E212-E215.

Lykos, T., G. Varga, and D. Casper. 1997. Varying degradation rates of total nonstructural carbohydrates: Effects on ruminal fermen- tation, blood metabolites, and milk production and composition in high producing Holstein cows. J. Dairy Sci. 80:3341-3355.

Madsen, T. G., L. Nielsen, and M. O. Nielsen. 2005. Mammary nutrient uptake in relation to dietary supplementation of rumen protected lysine and methionine in late and early lactating dairy goats. Small Rumin. Res. 56:151-164.

Mashek, D., K. L. Ingvartsen, J. B. Andersen, M. Vestergaard, and T. Larsen. 2001. Effects of a four-day hyperinsulinemic-euglycemic clamp in early and mid-lactation dairy cows on plasma concentrations of metabolites, hormones, and binding proteins. Domest. Anim. Endocrinol. 21:169-185.

Nielsen, M. O., K. Jakobsen, and J. N. Jorgensen. 1990. Changes in mammary blood flow during the lactation period in goats measured by the ultrasound Doppler principle. Comp. Biochem. Physiol. A 97:519-524.

Olesen, A.-L. 2002. Kontinuerlig laktation kræver god pasning. Bovilogisk Tidsskrift Kvæget 16:22-23.

Pardue, F. E., and E. W. Swanson. 1963. Mammary gland DNA as affected by dry periods. J. Dairy Sci. 46(Suppl. 1):625. (Abstr.)

Pitkow, H. S., R. P. Reece, and G. L. Waszilycsak. 1972. The integrity of mammary alveolar cells in two consecutive lactations (36250). Proc. Soc. Exp. Biol. Med. 139:845-850.

Quarrie, L. H., C. V. P. Assey, and C. J. Wilde. 1996. Programmed cell death during mammary tissue involution induced by weaning litter removal, and milk stasis. J. Cell. Physiol. 168:559-569.

Remond, B., and J. C. Bonnefoy. 1997. Performance of a herd of Holstein cows managed without the dry period. Ann. Zootech. 46:3-12.

Remond, B., J. Kerouanton, and V. Brocard. 1997a. The effect of reducing or omitting the dry period on the performance of dairy cows. Prod. Anim. 10:301-315.

Remond, B., A. Ollier, and G. Miranda. 1992. Milking of cows in late pregnancy: Milk production during this period and during the succeeding lactation. J. Dairy Res. 59:233-241.

Remond, B., J. Rouel, N. Pinson, and S. Jabet. 1997b. An attempt to omit the dry period over three consecutive lactations in dairy cows. Ann. Zootech. 46:399-408.

Sanders, H. G. 1928. The variations in milk yield caused by season of the year, service, age, and dry period, and their elimination. 4. Dry period and standardisation of yields. J. Agric. Sci. 18:209-251.

Shipman, L. J., A. H. Docherty, C. H. Knight, and C. J. Wilde. 1987. Metabolic adaptations in mouse mammary gland during a norma lactation cycle and in extended lactation. Q. J. Exp. Physiol. 72:303-311.

Smith, A., J. V. Wheelock, and F. H. Dodd. 1967. The effect of milking throughout pregnancy on milk secretion in the succeeding lactation. J. Dairy Res. 34:145-150.

Swanson, E. W. 1965. Comparing continuous milking with sixty day dry periods in successive lactations. J. Dairy Sci. 48:1205-1209.

Wilde, C. J., C. V. P. Addey, P. Li, and D. G. Fernig. 1997. Programmed cell death in bovine mammary tissue during lactation and involution. Exp. Physiol. 82:943-953. 